\title{
In vitro cytotoxic study for partially purified resveratrol extracted from grape skin fruit Vitis vinifera
}

\author{
دراسة للسميّة الخلوية لمادة Resveratrol المنقاة جزئياً والمستخلصة \\ من قشور ثمرة العنب Vitis vinifera في الزجاج
}

\author{
Zainab Y. Mohammed Essam F. Al-Jumaily ${ }^{*} \quad$ Nahi Y. Yaseen ${ }^{* *}$
}

Ibn Sina Research Center / Ministry of Mineral and Industry

* Genetic Engineering and Biotechnology Institute for Postgraduate

studies, Baghdad University

**Iraqi center for Caner and Medical Genetic Research

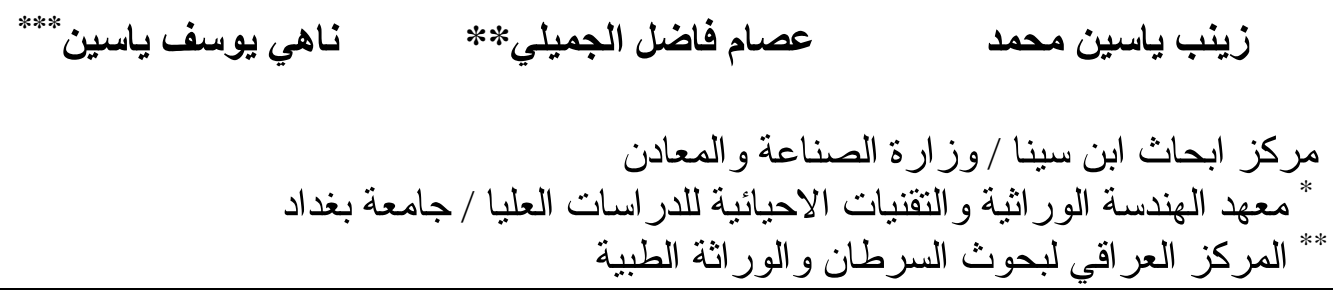

\begin{abstract}
The partial purified resveratrol was obtained from the skin of black grape fruit cultivated in Iraq using $80 \%$ ethanolic solution, then an acid hydrolysis with $10 \%$ $\mathrm{HCl}$ solution for $(10-30) \mathrm{min}$ at $60 \mathrm{C}$ ? was carried out. The aglycone moiety was taken with an organic solvent (chloroform), then using an open glass column packed with silica gelG 60 as a stationary phase and a mobile phase of; benzene: methanol: actic acid (20:4:1). The study utilized an in vitro evaluation for the cytotoxic effect of the partially purified resveratrol on some cell lines including, the murine mammary adenocarcinoma (Ahmed -Mohammed -Nahi-2003 -AMN -3) cell line; the human laryngeal carcinoma (Hep -2) cell line and the Rat Embryo Fibroblast (REF) cell line at different concentrations and different exposure time of treatment. The partial purified resveratrol extract concentrations ranging (7.84000) $\mu \mathrm{g} / \mathrm{ml}$ in a two fold serial dilutions were used to treat the three types of cell lines for 48 and 72 hours intervals. AMN-3 cell lines showed highest sensitivity toward the cytotoxic effect of the paritial purified resveratrol than other cell lines after 48 hours in a dose dependent manner. While Hep-2 cell line showed novel behavior, the lowest concentration of cell treatment gave the most significant $(P<$ 0.01) inhibitory effect. Only the highest concentration gave significant inhibitory effect $(P<0.01)$ with the transformed Ref cell line.

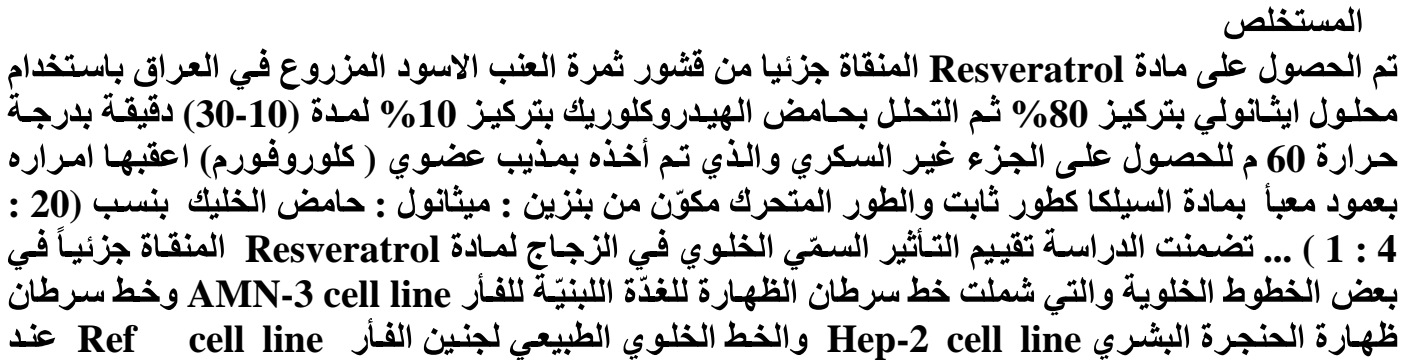




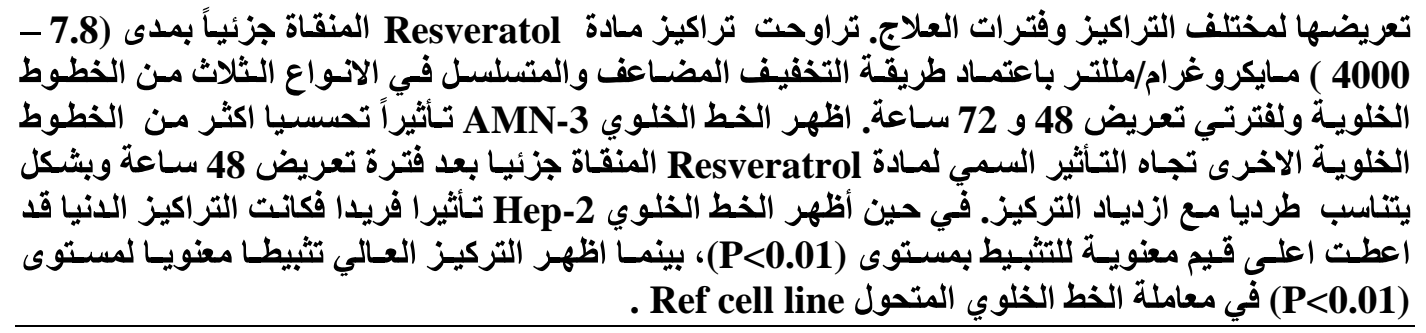

\section{Introduction}

The search for novel and effective cancer chemopreventive agents has led to the identification of various naturally occurring phytocompounds, one of which is resveratrol (trans- $3,4^{\prime}, 5-$ trihydroxy stilbene). It is a phytoalexin isolated from grape skin and other fruits [1], and black grape cultivated in Iraq is also rich in resveratrol [2]. Resveratrol has a potent anti-inflammatory, antioxidant, anti platelet aggregation effects and cardiovascular protection [3-5]. Moreover its potent chemopreventive and chemotheraputic activities have been demonstrated in all three stages of carcinogesis in numerous in vitro and in vivo studies [1,6]. It has the ability to modulate various targets and signaling pathways [7].

The use of in vitro assay system for cytotoxic screening is a common practice since the beginning of cancer chemotherapy in 1946, following the discovery of antineoplastic activity of nitrogen mustard. Some phytochemicals have been shown to exhibit cytotoxic effects against cancer cell through cell cycle modulation [8].

The secondary metabolite "Resveratrol" is synthesized by the plant in response to stress, including disease and ultraviolet light, and as a phytoalexin, it was first reported in skins of grapes by Creasy and Coffee [9] in 1988 and later in 1991 by Siemann and Creasy,but in wine[10].

Resveratrol is a non Flavonoid polyphenol has three phenolic hydroxyl groups which shown to give its biological effects such as; inhibition LDL oxidation [11]. Fresh grape skin contains (50-100) $\mu \mathrm{g} / \mathrm{g}$ of trans-resveratrol [12]. The potential for resveratrol to inhibit the development of cancer and extend lifespan in cell culture and animal models have continued to generate scientific interest [13].

The current study was aimed to:

1. Extraction and purification of one of the most important polyphenolic compound "Resveratrol" from the skin of black grape Vitis vinifera cultivated in Iraq.

2. In vitro cytotoxic study of the partial purified resveratrol on different types of cell lines at different concentrations and exposure times .

\section{Materials and Methods}

\section{Collection of samples}

Local black grapes cultivated in Iraq were collected from the local market and classified as Vitis vinifera by the herbarium of the Biology Department, College of Science, Baghdad University. The skin was separated from the fruit and kept in a dark cool place till the following steps.

\section{Preparation of grape skin extract}

Preparation of grape skin extract was according to Harborne (1984) [14]. About 500 grams of fresh skin grapes were shaken with 2.5 litters of $80 \%$ ethanol in cool dark place for 72 hours. The extract was filtered and the filtrate was dried at $30-40{ }^{\circ} \mathrm{C}$ by a rotary evaporator to get $1 / 10$ of its original volume, and stored at $-20^{\circ} \mathrm{C}$. 


\section{Acid Hydrolysis}

Acid hydrolysis was done using $10 \%(\mathrm{~V} / \mathrm{V}) . \mathrm{HCl}$ for $10-30$ minutes at $60^{\circ} \mathrm{C}$. This step led to the hydrolysis of the glycosidic linkage and got the aglycone moiety, which was cooled and filter [14].

\section{Liquid - Liquid Partion}

The filtrate was transferred to seperatory funnel. An organic solvent (chloroform) was added in a quantity equal to the aqueous phase, with gently shaking and repeating the process three times. The chloroform layers were collected together and washed from the access acid with distilled water. The collected chloroform layers were evaporated to dryness under vacuum with a rotary evaporator at $30^{\circ} \mathrm{C}$. The residue was green viscous alquest, which was stored in dark umber vessels at $-20^{\circ} \mathrm{C}$ untill use [14].

Column Chromatography (Partial Purification) by Solid - Liquid Adsorption Chromatography

A partial purification of the residue was carried out using open glass column $(2.5 \times 21)$ $\mathrm{cm}$ filled with silca gel G60 special for column chromatography. The residue was dissolved in 1-2 ml methanol and the mobile phase is benzene: methanol: acetic acid (20:4:1) [14].

The elutions were collected in 100 separated tubes each filled with $3 \mathrm{ml}$ eluent. All fractions were tested for $\mathrm{FeCl}_{3} 1 \%$ solution as a colourimeteric method for polyphenols identification $[14,15]$. Only the positive result elutions were collected and dried under vacuum by a rotary evaporator. The resveratrol spots were detected on a TLC aluminum sheet silica gel $60 \mathrm{~F}_{254}$ in comparison with the standard spot using the same mobile phase in the column chromatography.

The examined resveratrol spots under U.V.254nm lamb for both standard and the corresponding extract spot showed a light violet fluorescence [14].

\section{Cytotoxic Effect of Partial Purified Resveratrol on Cell Line: In vitro Study}

The in vitro method was used to investigate the effect of partially purified resveratrol on two types of tumor cell lines (Hep-2 and AMN-3 tumor cell lines ) and to compare the results with resveratrol effect on normal cell line Ref- 2 in different concentrations and at different exposure times .

\section{Partial purified resveratrol dilutions}

From the partial purified resveratrol, a stock solution was prepared by dissolving 100 $\mathrm{mg}$ in $0.01 \mathrm{ml}$ DMSO and the volume was make-up to $10 \mathrm{ml}$ with PBS, then it was filter-sterilized (Millipore $0.22 \mu \mathrm{m}$ filter). This stock was kept in a dark container at $20^{\circ} \mathrm{C}$. Immediately, serial dilutions were made starting from concentration $4000 \mu \mathrm{g} / \mathrm{ml}$ and ending with the concentration of $7.8 \mu \mathrm{g} / \mathrm{ml}$ under aspect conditions.

\section{Maintenance of the Cell Lines:}

When the cells in the flask formed a confluent monolayer, a Freshney's protocol was performed for cell line maintenance [16].

\section{Cytotoxicity Assay}

It is also called a cell growth inhibition assay. In this assay, the cell lines were treated with the partially purified resveratrol in ten concentrations ranging from $7.8 \mu \mathrm{g} / \mathrm{ml}$ to $4000 \mu \mathrm{g} / \mathrm{ml}$, using a microtiteration plate (96 wells) and during the log phase of the cells growth curve.

The effects were determined after the recovery time following the protocol assay, which included the following steps[16]: 
a. Seeding: The tryptinized and suspended cells were seeded in a microtiter plate by taking $0.2 \mathrm{ml}$ cell suspension into each well that might contain $\left(10^{4}-10^{5}\right)$ cells/well.

b. Incubation: All plates were incubated in $\mathrm{CO}_{2}$ incubator at $37^{\circ} \mathrm{C}$ for full cells attachment.

c. The treatment (or cells exposure): Using the maintenance medium (serum free medium) as a negative control and serum free medium with $0.1 \%$ DMSO as positive control, the microtiter plates after cells attachment were exposed to serial dilutions of the partially purified resveratrol in the concentrations rang mentioned before. The exposure times were 48 and 72 hours. Each plate was designed to contain three replications of each concentration and 12 wells for negative control and 12 wells for positive control.

d. Recovering times and reading the results: At the end of the exposure times the medium was decanted, the cells in the wells were gently washed by the addition of sterile PBS twice, and finally $50 \mu \mathrm{l}$ of crystal violate stain was added to the wells and the plates were incubated for 30 minutes at $37^{\circ} \mathrm{C}$, then the plates were washed gently with distilled water and left to dry.

The plates of different cell culture at the end of the assay were examined by ELISA reader at $492 \mathrm{~nm}$ transmitting wave length.

Only viable cells were able to take the stain, the dead cells were not. The proliferation rate was measured as follows [17]:

$$
\text { prolifiration rate }(\%)=\frac{\text { Absorbance at } 492 \mathrm{~nm} \text { of test }}{\text { Absorbance at } 492 \mathrm{~nm} \text { of control }} \quad X 100
$$

While the inhibitor rate was measured according to following equation [18]:

$$
\text { Inhibitor rate }(\%)=\frac{\text { Abs. at } 492 \mathrm{~nm} \text { control }- \text { Abs. at } 492 \mathrm{~nm} \text { t } 492 \mathrm{~nm} \text { of test }}{\text { Abs. at } 492 \mathrm{~nm} \text { of control }} \times 100
$$

All values were analyzed statically according to ASA (2001) program [19].

\section{Results and Discussion \\ Partial Purification}

It was done using silica gel G60 column chromatography technique with a mobile phase benzene: methanol: acetic acid (20:4:1) to elute fractions according to their affinity to mobile phase. The resultant fractions that gave positive ferric chloride test $1 \%$ solution were detected by T.L.C silica gel $60 \mathrm{~F}_{254}$ plate with the same mobile phase [20].

The dried collection was designated as "Partial purified resveratrol". Figure (1) showed the T.L.C chromatogram for detection partial purified resveratrol (the +ve result of $1 \%$ $\mathrm{FeCL}_{3}$ test). 


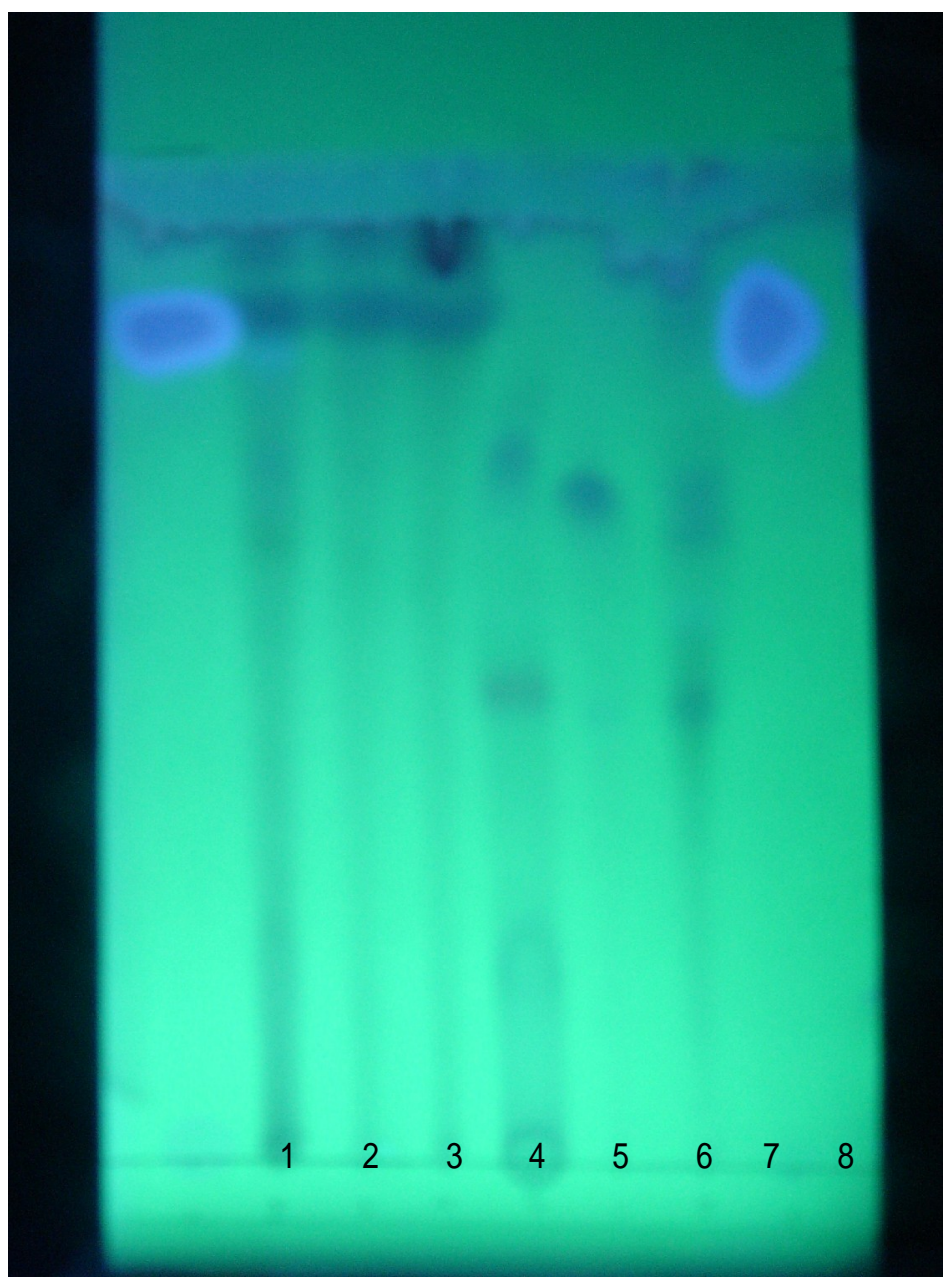

Fig (1) T.L.C chromatogram for detection partial purified resveratrol under UV lamp $(254 \mathrm{~nm})$ the positive and negative results of $1 \% \mathrm{FeCl}_{3}$ test

Spot (1) and (8): $1 \mu \mathrm{l}$ of $0.1 \%$ solution trans- resveratrol standard

Spot (2), (3) and (4): $1 \mu$ of partially purified resveratrol gives positive results with $1 \% \mathrm{FeCl}_{3}$

Solution after column chromatography.

Spot (5), (6) and (7): $1 \mu \mathrm{l}$ of extract after column chromatography gives negative results with $1 \%$ $\mathrm{FeCl}_{3}$ solution

\section{Cytotoxic Effect "Growth Inhibitory Assays of the Partial Purified Resveratrol}

Three cell lines were studied (AMN-3, Hep-2, Ref cell lines) at two times of exposure (48 and 72 hour), using a two fold dilutions to get concentration from $7.8 \mu \mathrm{g} / \mathrm{ml}$ to 4000 $\mu \mathrm{g} / \mathrm{ml}$ of partial purified resveratrol

a. The cytotoxic effect on AMN-3 cell line (passage number 103): Figure (2) revealed that the high concentrations gave a significantly $(\mathrm{P}<0.01)$ high inhibition rate of cells while being low gradually with low concentrations.

After 48 hours of exposure a low cytotoxic inhibitory effect $(-5 \%)$ of the extract was started at the concentration $(500 \mu \mathrm{g} / \mathrm{ml})$, and the effect was increased significantly 
$(\mathrm{P}<0.01)$ at concentration $1000 \mu \mathrm{g} / \mathrm{ml}$ to give cytotoxic inhibition rate of $(-14.12 \%)$. The highest significant effect $(-38.23 \%)$ was shown at concentration $4000 \mu \mathrm{g} / \mathrm{ml}$. For 72 hours of exposure the extract showed a weak cytotoxic effect $(-1.5 \%)$ at the concentration $4000 \mu \mathrm{g} / \mathrm{ml}$, and more cytotoxic inhibitory effect $(-10 \%)$ at concentration $2000 \mu \mathrm{g} / \mathrm{ml}$, while a low growth simulating effects for the other concentrations. The extracted polyphenol partial purified resveratrol was very sensitive and liable through many environmental changes even with suitable protection which led to get the best results at 48 hours of exposure than after 72 hours of cells treatments. This might explain the more significant inhibition rate at different concentration for 48 hours than 72 hours of exposure.

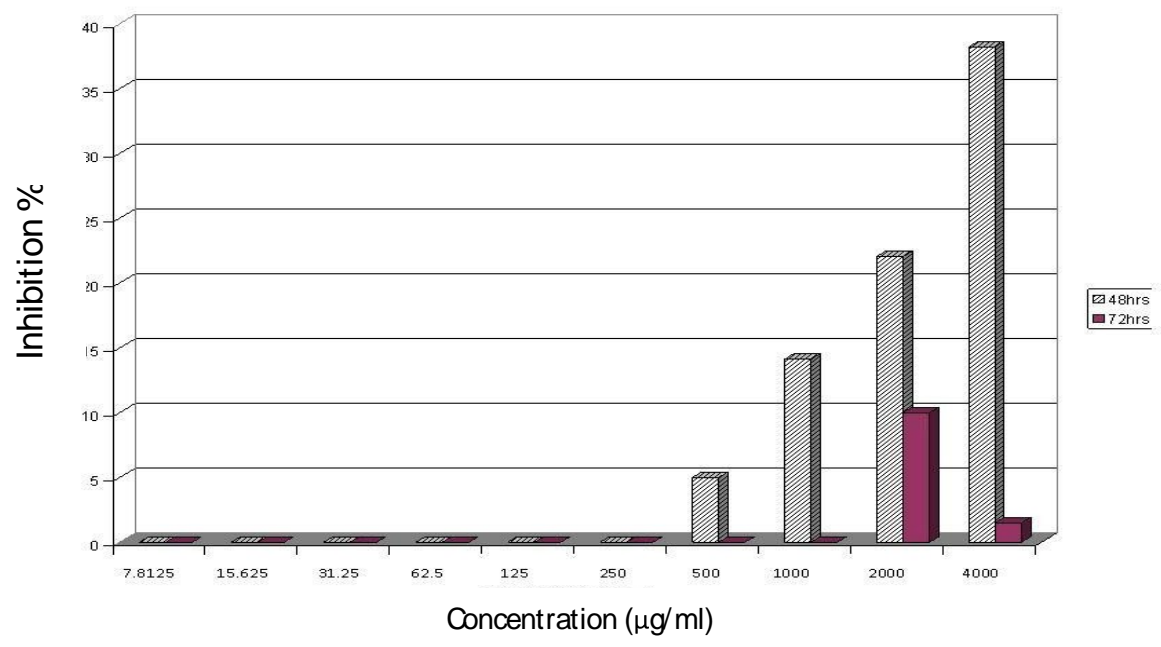

Fig(2): Inhibition rate (\% IR) histogram for different concentrations of partial purified resveratrol on $\mathrm{AMN}-3$ cell line

b. cytotoxic effect on Hep-2 cell line :

The study was done on Hep-2 cell line (passage number 228-230): The effect of the partial purified resveratrol on Hep-2 cell line was shown in Figure (3).

The results showed novel behaviour for Hep-2 cell line than other cultured cells.

After 72 hours of exposure time, a significant inhibition rate $(-15.27 \%)$ started at the concentration $4000 \mu \mathrm{g} / \mathrm{ml}$, while no cytotoxic effect of the same concentration after 48 hours of exposure. As the concentration decreased there was a decline in the inhibitory effect with no significant effect at the concentration $(500,250,125) \mu \mathrm{g} / \mathrm{ml}$ for 48 hours and at the concentration $(2000,1000,500,250,125,62.5) \mu \mathrm{g} / \mathrm{ml}$ for the 72 hours time of the exposure. After 48 hours of exposure, there was a significant $(\mathrm{P}<0.01)$ effect at the concentrations $(62.5,31.25,15.625,7.8125) \mu \mathrm{g} / \mathrm{ml}$ to give growth rate inhibition of $(-11 \%,-15 \%,-19.66 \%,-10.8 \%)$ respectively, and after 72 hours of exposure the concentrations $(31.25,15.625,7.8125) \mu \mathrm{g} / \mathrm{ml}$ showed a significant $(\mathrm{P}<0.01)$ inhibition rate of $(-24.32 \%,-25.67 \%,-28.37 \%)$ respectively .

An explanation for this behaviour, that in the design of cell culture experiment it was important to be aware of the growth state of the culture, as well as the quantitative characteristics of cell strain or cell line. Cultures will vary significantly in many of their properties between exponential growth and stationary phase [16]. 


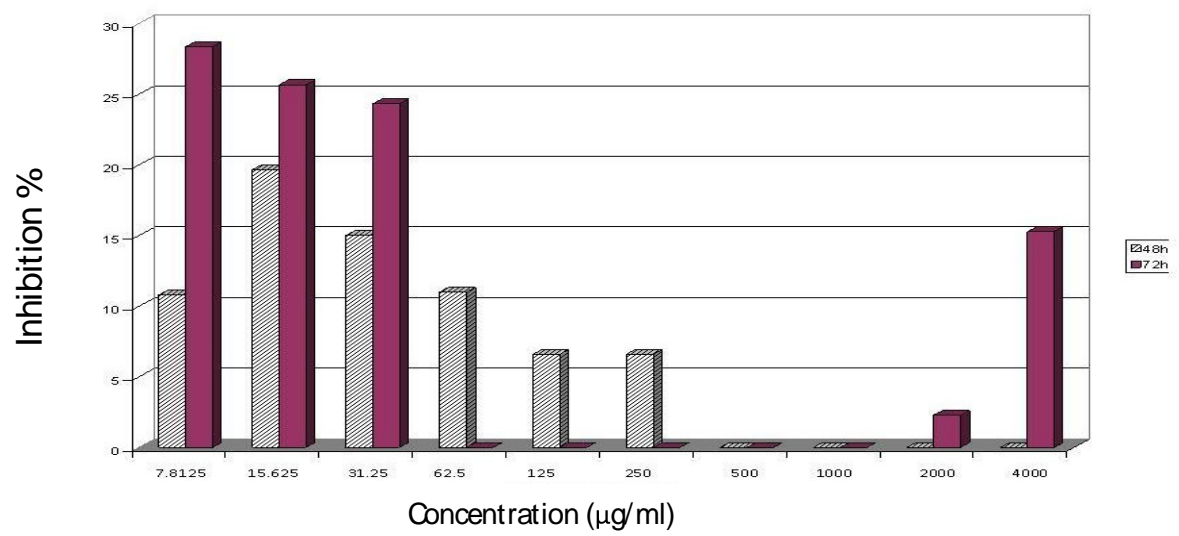

Fig(3): Inhibition rate (\% IR) histogram for different concentrations of partial purified resveratrol on Hep-2 cell line

c. Cytotoxic effect on Ref cell line:

The results of treating Ref. cell line passage number (75) with the partial purified resveratrol are presented in Figure (4).

For the 48 hours of exposure, the cell growth inhibition reached its highest cytotoxic effect $(-32.23 \%)$ at the concentration $4000 \mu \mathrm{g} / \mathrm{ml}$, which was significant $(\mathrm{P}<0.01)$, then the cytotoxic effect showed no significance for the concentrations $2000 \mu \mathrm{g} / \mathrm{ml}$ till the concentration $7.8 \mu \mathrm{g} / \mathrm{ml}$, and a stimulation of cell growth appeared. After 72 hours of treatment, only a significant $(\mathrm{P}<0.05)$ cytotoxic inhibitory effect $(-12.69 \%)$ appeared at the concentration $4000 \mu \mathrm{g} / \mathrm{ml}$, other concentrations showed no inhibitory effects, the cells revealed a non significant growth stimulation.

Adding a drug (or plant extract) in the middle of the exponential phase and assaying later this may give different results, depending on whether the culture is still in exponential growth when harvested or whether it had entered plateau [16].

Most normal cells had a finite life-span of 20-100 generations but some cells, notably those from rodents (and from most tumors), could produce continuous cell lines with an infinite life- span [16]. Ref cell line was a rat embryo fibroblast which was represented as a normal cell line may undergo a further transformation at passage number (75) and gave rise to continous cell lines. This fact gave an explanation of the Ref transformed cell line behaviours towards the cytotoxic effect of partial purified resveratrol as well as other cancer cell line AMN-3 and Hep-2.

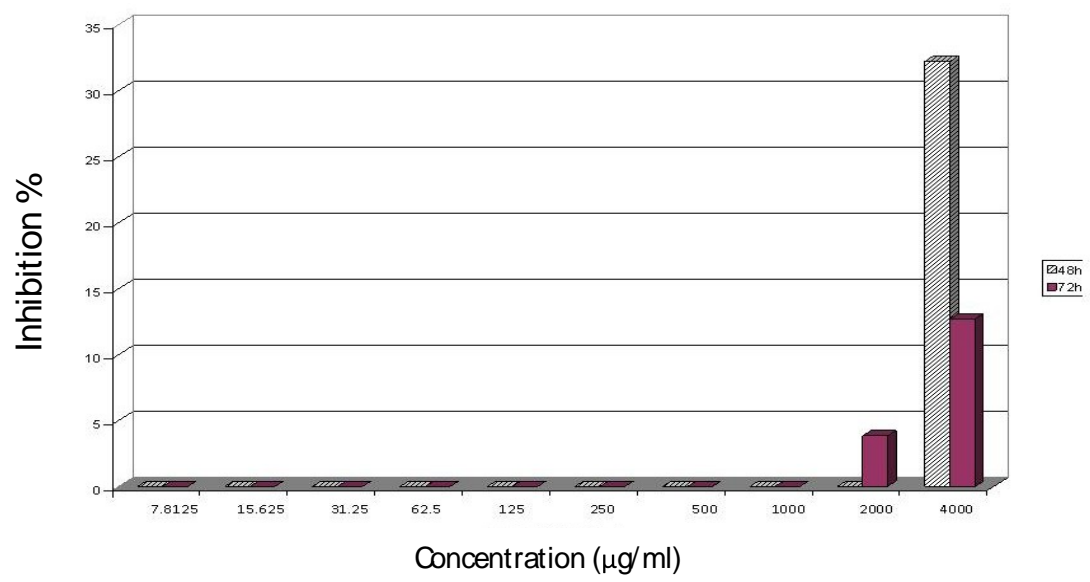

Fig(4): Inhibition rate (\%IR) histogram for different concentrations of partial purified resveratrol on Ref cell line 


\section{References}

1. Ather,M.; Back, J.H.; Tang, X. and Bickers, D.R. 2007. Resveratrol: A review of preclinical studies for human cancer prevention. Toxicology and Applied Pharmacology. 224: 274-283.

2. Al-Malikey, Z.S.L. 2004. Studing content of some local grapes varieties vitis vinifera L. from phenolic compounds. Ph.D. thesis, College of Agriculture Univ. of Baghdad, Iraq.

3. Candelario- Jalil, E. ; de Oliveiva, A.C.P. ; Graf, S.; Bhatia, H.S. and Fiebich, B.L. 2007. Resveratrol potently reduces prostaglandin E2 production and free radical formation in lipopoly schaccharide activated primary rat microglia . Neuroinflammation. 4: 25-41.

4. Gao, D.; Zhang, X.; Tiang, X.; Peng, Y. and Song, L. 2002. Resveratrol reduces the elevated level of MMp-9 induced by cerebral ischemia - Reperfusion Institute of Neurosurger . China.

5. Singletary, K.2000. Diet natural products and cancer prevention. J. Nutr. 130: 465466.

6. Erickson,L. 2003. Rooibos tea: Resveratrol into antioxidant and antimutagenic properties. The Journal of American Botanical Council, 59: 34-45.

7. Niles, R.M; Mcfarland, M. and Meadows, GG, 2003. Resveratrol is a potent inducer of apoptosis in human medanoma cells. Cancer lelt. 190: 157-163.

8. Rana, P. ; Singha,M.; Sivanandhan, D. and Rajesh, A. 2002. Phytochemicals as cell cycle modulators. Cell Cylcle, 2: 25-33.

9. Creasy, L.L. and Cooffe, M. 1988. Poltoalexin production potential of grape berries J.Am.Soc. Hort. Sci. $113: 230-234$

10. Siemann, P. and Creasy L.L. 1991. Method to assay ployphenolic constituent in wine. An alchemy. 24:77-86.

11. Tomas- Barberan, F.A. and Robins, R. J. 1997. Phytochemistry of fruit and vegetables. Clarendon press- Oxford. New York.

12. Hendler , S.S and Rorvik, D. 2001. Resveratrol In: PDR for Nutritional Supplements. Medical Economics, Thomson Healthcare, Montrale.

13. Howitz, K.T.; Bitterman, K.J.; Cohen, H.Y.; Lamming, D.W.; Lavu, S.; Wood, J.G.; Zipkin, R.E.; Chung, P.; Kisielewski, A., Zhang, L.L.; Scherer, B. and Sinclair, D.A. 2003. Small molecule activators of sirtuins extend Saccharomyces cerevisiae lifespan. Nature. 11:191-196.

14. Harborne, J.B., 1984. Phytochemical Methods. Chapman and Hall. London.

15. Sharma, K.K. 1992. An introduction to practical, chemistry. New Delhi. India.

16. Freshney, R.I. 1994. Culture of animal cells. Third Edition. Wiley- Liss. New York.

17. Chumchalova, J. and Smarda, J. 2003. Human tumor cells are selectively inhibited by colicins . Folia Microbiol. 48: 111-115.

18. Gao, S.; Yu, B.; Li, Y.; Dond ,W. and Luo, H. 2003. Antiproliferative effect of Octreotide on gastric cells mediated by inhihibition of AKt/pKB telomerase. World J. Gastroenterol, 9: 2362-2365.

19. SAS. 2001. SAS/STAT user's guide for personel computers release. 6.12. SAS. Inst. Inc. Cary. NC. USA.

20. Mohammed, Z. Y. 2008. Study the effect of the polyphenolic compounds extracted from grape skin fruit Vitis vinifera on some cell lines (in vitro), M.Sc. Thesis, Institute of Genetic eng. and Biotech. for postgraduate studies, University of Baghdad. 